Check for updates

Cite this: RSC Adv., 2020, 10, 40552

\title{
Tin(II) chloride dihydrate/choline chloride deep eutectic solvent: redox properties in the fast synthesis of $\mathrm{N}$-arylacetamides and indolo(pyrrolo) [1,2-a]quinoxalines $\dagger$
}

\author{
Sergio Alfonso Trujillo, ${ }^{a}$ Diana Peña-Solórzano, ${ }^{a}$ Oscar Rodríguez Bejarano ${ }^{b}$ \\ and Cristian Ochoa-Puentes (ID)*a
}

In this contribution a physicochemical, IR and Raman characterization for the tin(II) chloride dihydrate/ choline chloride eutectic mixture is reported. The redox properties of this solvent were also studied by cyclic voltammetry finding that it can be successfully used as an electrochemical solvent for electrosynthesis and electroanalytical processes and does not require negative potentials as verified by the reduction of nitrobenzene. The potential use of this eutectic mixture as a redox solvent was further explored in obtaining aromatic amines and $\mathrm{N}$-arylacetamides starting from a wide variety of nitroaromatic compounds. In addition, a fast synthetic strategy for the construction of a series of indolo(pyrrolo)[1,2-a]quinoxalines was developed by reacting 1-(2-nitrophenyl)- $1 \mathrm{H}$-indole(pyrrole) with aldehydes. This simple protocol offers a straightforward method for the construction of the target quinoxalines in short reaction times and high yields where the key step involves a tandem one-pot reductive cyclization-oxidation.

Received 9th August 2020
Accepted 16th October 2020

DOI: $10.1039 / \mathrm{d} 0 \mathrm{ra06871c}$

rsc.li/rsc-advances

\section{Introduction}

Nitro compounds are versatile nitrogenated molecules found in natural products and synthetic derivatives. Its isolation from plants, bacteria, fungi, and mammals has allowed the discovery of several bioactive compounds which exhibited a high structural diversity together with antibiotic, ${ }^{1,2}$ antitumor $^{3}$ and immunosuppressive ${ }^{4}$ activities. Different synthetic derivatives have been also employed as solvents, agrochemicals, ${ }^{5}$ drugs, dyes $^{6}$ and fine chemicals.

Due to their reactivity, nitro compounds are considered as versatile synthetic tools and, in particular, aliphatic nitro compounds are suitable starting materials to perform carboncarbon bond forming reactions such as nitro-Mannich, Henry, and nitro-Michael reactions..$^{7-9}$ They are also fundamental building blocks employed in the synthesis of amines which are obtained by the reduction of the nitro group through metalacid combinations, catalytic hydrogenation, hydride transfer

\footnotetext{
${ }^{a}$ Laboratorio de Sintesis Orgánica Sostenible, Departamento de Química, Universidad Nacional de Colombia-Sede Bogotá, Carrera 45 \# 26-85, A.A. 5997, Bogotá, Colombia. E-mail: cochoapu@unal.edu.co

${ }^{b}$ Laboratorio de Electroquimica y Termodinámica Computacional, Departamento de Química, Universidad Nacional de Colombia-Sede Bogotá, Carrera 45 \# 26-85, A.A. 5997, Bogotá, Colombia

$\dagger$ Electronic supplementary information (ESI) available: Characterization data for all compounds and selected ${ }^{1} \mathrm{H}$ and ${ }^{13} \mathrm{C}-\mathrm{NMR}$ spectra. See DOI: 10.1039/d0ra06871c
}

reductions, catalytic transfer hydrogenation and metal-free reduction methods. ${ }^{10}$ The synthetic utility of this transformation is highlighted in several one pot procedures for the obtention of diverse structures including imines, amides ${ }^{11}$ and $\alpha$-aminophosphonates ${ }^{12}$ together with heterocyclic compounds such as benzimidazoles, ${ }^{13-15}$ quinazolinones, ${ }^{16,17}$ pyrrolines, ${ }^{18}$ isoindolinone derivatives, ${ }^{19}$ tetrahydroquinolines, ${ }^{20-23}$ and quinoxalines, ${ }^{24,25}$ where a tandem one-pot reduction and intramolecular cyclization reaction is achieved.

Among the different nitrogenated heterocycles, quinoxalines are considered privileged structures with broad medicinal and industrial applications. This bioactive motif is found in marketed drugs with antibiotic, antibacterial, antitumor, antiviral, antifungal, anti-inflammatory, antimicrobial activities, ${ }^{26}$ while many more are under study for potential biomedical applications (Fig. 1). ${ }^{27}$

Besides the pharmaceutical interest, various synthetic derivatives have also found applications in organic electronics, ${ }^{28-30}$ dyes, ${ }^{31}$ chemically controllable switches ${ }^{32}$ cavitands and macrocyclic receptors. ${ }^{33-35}$

Within the diverse structural derivatives reported in literature for this heterocyclic system, the indolo(pyrrolo)[1,2-a]quinoxalines have attracted much interest from the synthetic and biological community. Considering the integrity of the benzene ring, the construction of this polycyclic skeleton follows different strategies depending on the number of atoms contained in each fragment. Thus, synthetic equivalents with 


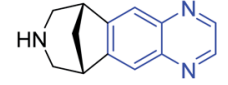<smiles>Nc1ccc(S(=O)(=O)Nc2cnc3c(Cl)cccc3n2)cc1</smiles>

Verenicline

Chloroquinoxaline Sulfonamide<smiles>Cc1nc(-c2ncn3c2CN(C(C)C)c2ccccc2-3)no1</smiles>

Panadipion<smiles>O=c1cc2n(CC(O)C(O)C(O)O)c3ccccc3nc-2c(=O)[nH]1</smiles>

Riboflavin (Vitamin $\mathrm{B}_{2}$ )

Fig. 1 Representative bioactive and naturally occurring quinoxalines.

several combinations of atoms might be used. On the other hand, a more convenient strategy based on pyrrole or indole derivatives can be developed for the formation of the pyrazine ring; ${ }^{36}$ and for this 1-(2-aminophenyl)pyrrole/indole has been widely used as starting material in combination with a broad scope of substrates including aldehydes, ${ }^{37-40}$ alcohols, ${ }^{41}$ ketones ${ }^{42,43} \alpha$-aminoacids, ${ }^{44}$ carboxylic acids, ${ }^{45}$ 2-methylpyridine/quinoline ${ }^{46}$ and benzylamines ${ }^{47}$ (Scheme 1). Analogously, other synthetic approaches have employed arylhalides, ${ }^{48}$ arylisocyanides, ${ }^{49}$ and nitrobenzene ${ }^{24}$ having ortho-substituted pyrrole or indole rings (Scheme 1).

Although the methods depicted before are ingeniously developed and represent new alternatives for the obtention of the indolo(pyrrolo)[1,2-a]quinoxaline skeleton, some of them suffered from several disadvantages such as the use of strong oxidizing agents, ligands and costly catalysts, require an elaborated set up, and have long reaction times with moderated yields. Keeping this in mind, we envisioned that the tin(II) chloride dihydrate/choline chloride deep eutectic solvent (DES) might be a suitable reductive reaction medium to obtain the target compounds starting from 1-(2-nitrophenyl)-indole/ pyrrole and aldehydes via a one-pot reductive cyclization strategy (Scheme 1). The use of tin(II) chloride/choline chloride DES in organic synthesis has been previously introduced by Azizi $^{50}$ and Tavakol. ${ }^{51,52}$ The first author found that this eutectic mixture effectively catalyses the ring opening of epoxides by a range of nucleophiles (amines, thiols, alcohols, cyanide and azide) providing the target products with good chemo, regio, and stereoselectivity. ${ }^{50}$ On the other hand, Tavakol developed an environmentally friendly synthesis of quinoline derivatives via a one-pot multi-component reaction between aryl aldehydes, aniline derivatives and enolizable aldehydes employing the $\mathrm{ChCl} / \mathrm{SnCl}_{2}$ DES as a green catalyst and solvent. ${ }^{51}$ The same author also reported the synthesis of xanthene derivatives by the

$$
\begin{aligned}
& \begin{array}{l}
\mathrm{O}_{4}, \mathrm{DCM}, 1 \mathrm{~h} . \text { ref. } 37 \\
\mathrm{CH}_{3} \mathrm{CN}, \mathrm{rt}, 12 \mathrm{~h} \text {. ref. } 40
\end{array} \\
& \overbrace{\substack{n \\
N}}^{+}\rceil_{P_{6}} \\
& \mathrm{R}_{\text {excess }} \\
& \mathrm{O}_{2}, 160^{\circ} \mathrm{C}, 12 \mathrm{~h} \text {. ref } 41
\end{aligned}
$$

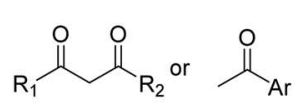

$$
\begin{aligned}
& \mathrm{I}_{2}(20 \mathrm{~mol} \%) \text {, DMSO } \\
& 120{ }^{\circ} \mathrm{C} \text {, 6h. ref. } 42 \\
& \mathrm{TsOH} \mathrm{H} \mathrm{H}_{2} \mathrm{O}, \mathrm{DMSO} \text {, rt or } \\
& 120^{\circ} \mathrm{C}, 12 \mathrm{~h} \text {. ref. } 43
\end{aligned}
$$

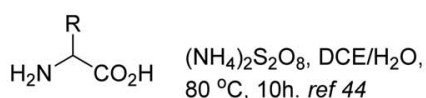

$$
\begin{aligned}
& \prod_{0}^{\mathrm{OH}} \begin{array}{l}
\mathrm{CuSO}_{4}(10 \mathrm{~mol} \%), \text { Bipyridyl }(20 \%), \\
\mathrm{DMF}, \mathrm{O}_{2}, 130^{\circ} \mathrm{C}, 8 \mathrm{~h} . \text { ref. } 45
\end{array} \\
& \begin{array}{ll}
\mathrm{Cu}(\mathrm{OAC})_{2}(10 \mathrm{~mol} \%), \mathrm{TFA}, \\
\mathrm{DMF}, 120^{\circ} \mathrm{C}, \mathrm{O}_{2}, 12 \mathrm{~h} \text {. ref. } 46
\end{array} \\
& \mathrm{H}_{2} \mathrm{~N}, \mathrm{MeCN}, 80^{\circ} \mathrm{C}, 5-8 \mathrm{~h} \text {. ref } 47
\end{aligned}
$$<smiles>[R]c1nc2ccccc2n2c1cc1ccccc12</smiles><smiles></smiles>
$\mathrm{X}=\mathrm{Br}, \mathrm{I}$
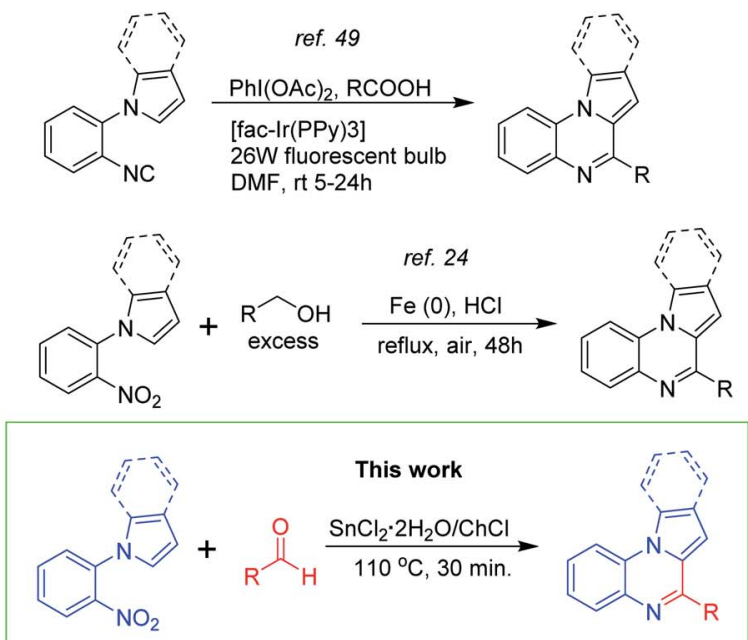

Scheme 1 Synthetic strategies for the synthesis of indolo(pyrrolo)[1,2-a]quinoxalines. 
reaction between 2-naphthol derivatives and aromatic or aliphatic aldehydes in the presence of the DES..$^{52}$ Other applications of this eutectic mixture include the extractive desulfurization of liquid fuels $\mathrm{s}^{53}$ and its use as catalysts for epoxy resin crosslinking. ${ }^{54}$

\section{Results and discussion}

Before starting the synthetic studies of this work, we first performed a physicochemical characterization and investigated the redox properties of the tin(II) chloride dihydrate/choline chloride DES in order to gain more insight into the properties and potential applications for this solvent.

The FTIR spectra of pure choline chloride (a), $\mathrm{SnCl}_{2} \cdot 2 \mathrm{H}_{2} \mathrm{O}$ (b) and the DES (c) are presented in Fig. 2. For choline chloride, the FTIR spectrum shows the characteristic bands associated to the $\mathrm{OH}, \mathrm{CH}_{2}, \mathrm{CH}_{3}$ and $\mathrm{C}-\mathrm{N}^{+}$groups at $3200 \mathrm{~cm}^{-1}$ (O-H stretch), $1470-1440 \mathrm{~cm}^{-1}\left(\mathrm{CH}_{3}\right.$ and $\mathrm{CH}_{2}$ bend), $1050 \mathrm{~cm}^{-1}$ (C-O stretch) and $882 \mathrm{~cm}^{-1}$ (C- $\mathrm{N}^{+}$symmetric stretching). Similarly, the FTIR spectrum of pure $\mathrm{SnCl}_{2} \cdot 2 \mathrm{H}_{2} \mathrm{O}$ (Fig. 2b) showed the usual broad band of stretching vibrations of the $\mathrm{OH}$ bond between 3100 and $3500 \mathrm{~cm}^{-1}$ together with the bending $\mathrm{H}-\mathrm{O}-\mathrm{H}$ vibrations in the region between $1610-1620 \mathrm{~cm}^{-1}$, while absorption bands below $900 \mathrm{~cm}^{-1}$ belong to $\mathrm{Sn}-\mathrm{Cl}$ and $\mathrm{Sn}-\mathrm{OH}$ bonds. These spectra agree with others previously published..$^{55,56}$ On the other hand, it is observed that several bands corresponding to choline chloride co-exist after the DES formation (Fig. 2c). However, a vibrational broad band appears at $3500 \mathrm{~cm}^{-1}$ which is assigned to the $\mathrm{O}-\mathrm{H}$ stretching. This band broadens because of the presence of water molecules indicating the formation of hydrogen bonds. The bending $\mathrm{H}-\mathrm{O}-\mathrm{H}$ vibration appears in the region between $1615-1624 \mathrm{~cm}^{-1}$, and the absorption corresponding to C-N $\mathrm{N}^{+}$symmetric stretching is observed at $869 \mathrm{~cm}^{-1}$.

The Raman spectra for choline chloride (a), $\mathrm{SnCl}_{2} \cdot 2 \mathrm{H}_{2} \mathrm{O}$ (b) and the DES (c) are depicted in Fig. 3. It could be seen that Raman spectra of $\mathrm{ChCl}$ presents bands in the range of 2800$3100 \mathrm{~cm}^{-1}$ which are assigned to anti-symmetric and symmetric

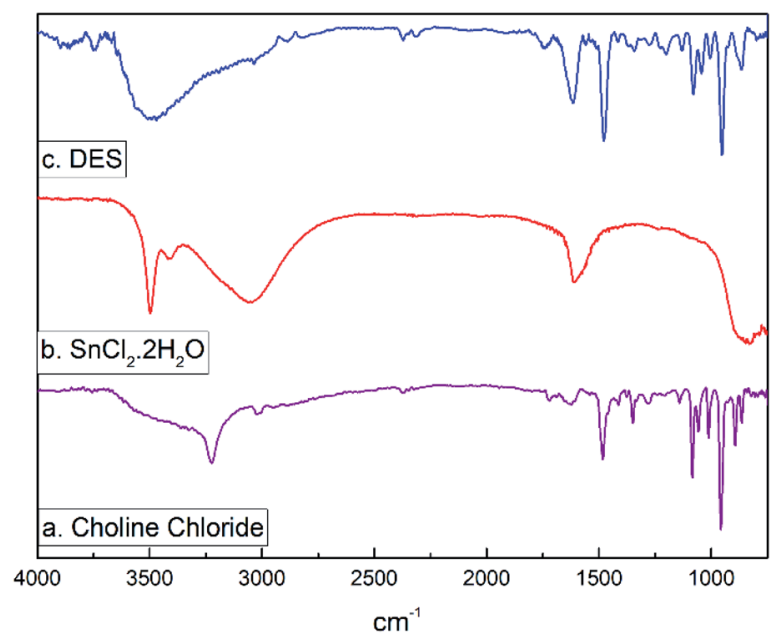

Fig. 2 FTIR spectrum for (a) choline chloride, (b) tin(॥) chloride dihydrate, and (c) the eutectic mixture $\mathrm{SnCl}_{2} \cdot 2 \mathrm{H}_{2} \mathrm{O} / \mathrm{ChCl}$.

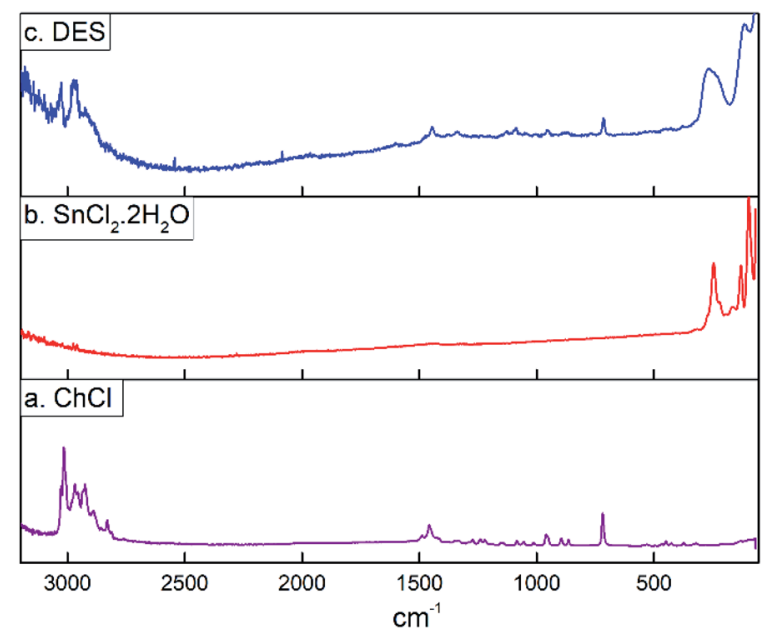

Fig. 3 Raman spectrum for (a) choline chloride, (b) tin(॥) chloride dihydrate, and (c) the eutectic mixture $\mathrm{SnCl}_{2} \cdot 2 \mathrm{H}_{2} \mathrm{O} / \mathrm{ChCl}$.

$\mathrm{CH}_{2}$ and $\mathrm{CH}_{3}$ stretching vibrations. Bands assigned to $\mathrm{CH}_{3}$ and $\mathrm{COH}$ deformations are at $1410-1430 \mathrm{~cm}^{-1}$ and the Raman band at $720 \mathrm{~cm}^{-1}$ can be assigned to the symmetric stretching vibration of the four $\mathrm{C}-\mathrm{N}$ bonds. ${ }^{57,58}$ The Raman spectra of tin(II) chloride dihydrate shows peaks in frequencies below $300 \mathrm{~cm}^{-1}$. It is known that the unit cell of $\mathrm{SnCl}_{2} \cdot 2 \mathrm{H}_{2} \mathrm{O}$ contains four molecules of the pyramidal dichloroaquatin(II) complexes, $\mathrm{SnCl}_{2}\left(\mathrm{H}_{2} \mathrm{O}\right)$, and this coordinated water molecule at an apex of each pyramid forms a two-dimensional hydrogen bonded network with another noncoordinating water molecule. Based on this, Raman frequencies in the range from 52 to $222 \mathrm{~cm}^{-1}$ has been attributed to the deformation and stretching modes of the $\mathrm{Cl}-\mathrm{Sn}-\mathrm{Cl}, \mathrm{Cl}-\mathrm{Sn}-\mathrm{O}$ and $\mathrm{Sn}-\mathrm{Cl}$ groups, while the band at $247 \mathrm{~cm}^{-1}$ corresponds to the $\mathrm{O}-\mathrm{H} \cdots \mathrm{O}$ hydrogen bonded network. ${ }^{59}$ It could be seen that Raman spectra of $\mathrm{SnCl}_{2} \cdot 2 \mathrm{H}_{2} \mathrm{O} /$ $\mathrm{ChCl}$ DES present a combined spectrum of the two components where the broad band at $254 \mathrm{~cm}^{-1}$ suggest the formation of hydrogen bonds between $\mathrm{ChCl}$ and $\mathrm{SnCl}_{2} \cdot 2 \mathrm{H}_{2} \mathrm{O}$ through water molecules from $\mathrm{SnCl}_{2} \cdot 2 \mathrm{H}_{2} \mathrm{O}$ and $\mathrm{Cl}^{-}$and $\mathrm{OH}$ groups from ChCl.

Next, the refractive index $\left(n_{\mathrm{D}}\right)$, conductivity $(k)$ and density $(\rho)$ were studied as function of temperature in the range from 35 to $80{ }^{\circ} \mathrm{C}$. The temperature dependence of the refractive index is shown in Fig. 4. The refractive index shows a decrease when the temperature is increased lying in the range from 1.6420 to 1.6304 and it has higher values compared to common polar protic and aprotic organic solvents such as hexamethylphosphoramide (HMPT), $N$-methylacetamide (NMA), $N, N$-dimethylacetamide (DMA), dioxane, acetonitrile, $N$-methylformamide (NMF), and methanol. ${ }^{60}$

The temperature-dependent behaviour of refractive index was fitted linearly according with the eqn (1) where $n_{\mathrm{D}}$ is the refractive index, $t$ is the temperature, $a$ and $b$ are unitless terms given in Table 1.

$$
n_{\mathrm{D}}=a\left(t /^{\circ} \mathrm{C}\right)+b
$$




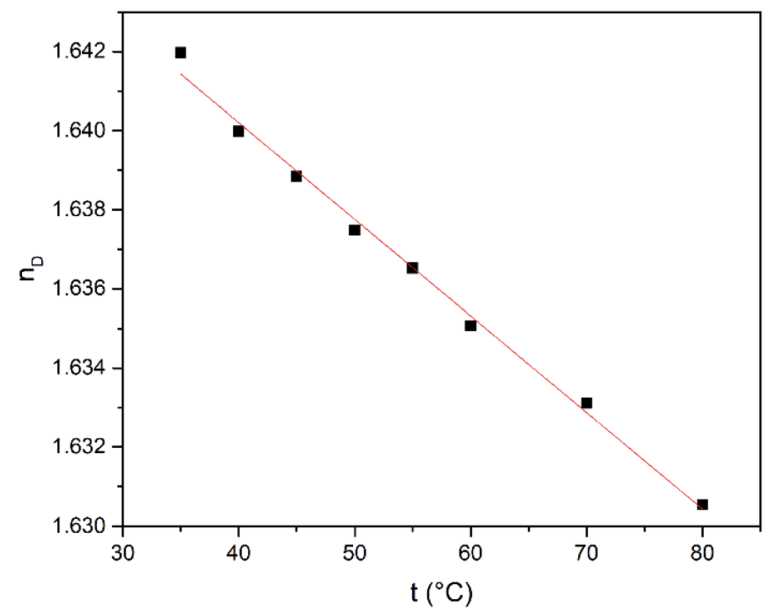

Fig. 4 Refractive index $\left(n_{\mathrm{D}}\right)$ of $\mathrm{SnCl}_{2} \cdot 2 \mathrm{H}_{2} \mathrm{O} / \mathrm{ChCl}$ as a function of temperature.

Table 1 Values of parameters $a, b, k_{0}, E_{\mathrm{k}} / R$ and correlation coefficient for eqn (1)-(3)

\begin{tabular}{llll}
\hline \multirow{2}{*}{$\begin{array}{l}\text { Parameters and correlation } \\
\text { coefficient }\end{array}$} & \multicolumn{2}{l}{ Physical properties } \\
\cline { 2 - 3 } & $n_{\mathrm{D}}$ & $k$ & $\rho$ \\
\hline$a$ & $-3 \times 10^{-4}$ & & $-1.1 \times 10^{-3}$ \\
$b$ & 1.651 & $2.42 \times 10^{-4}$ & 2.0808 \\
$k_{0}$ & & 645.8 & \\
$E_{\mathrm{k}} / \mathrm{R}$ & & 0.9995 & 0.9993 \\
$R^{2}$ & 0.9902 & &
\end{tabular}

In contrast to refractive index, higher values for conductivity are observed at elevated temperatures (Fig. 5) which shows an increase in the kinetic energy of all species that coexist in the DES.

The dependence between conductivity and temperature is modelled with the Arrhenius-like eqn (2), where the values of $k_{0}$ and $\left(E_{\mathrm{k}} / R\right)$ are shown in Table 1.

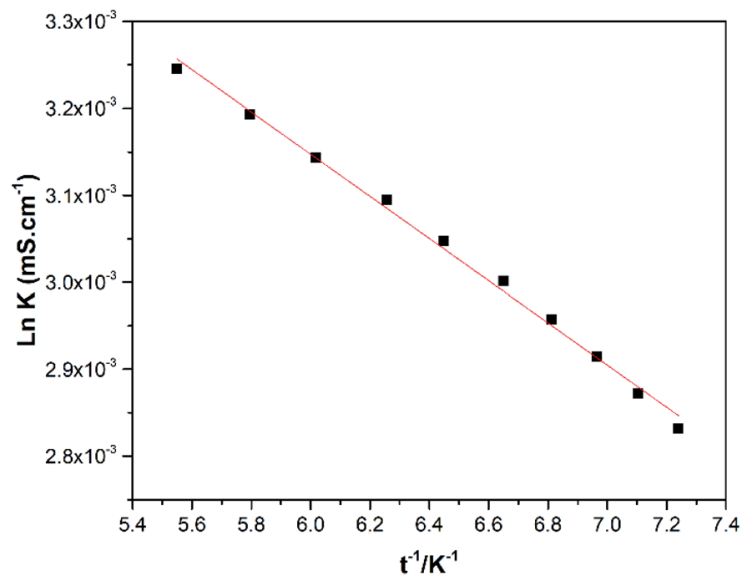

Fig. 5 Conductivity as a function of temperature for the $\mathrm{SnCl}_{2} \cdot 2 \mathrm{H}_{2} \mathrm{O}$ / ChCl DES.

$$
\ln k=\ln k_{0}-\left(E_{\mathrm{k}} / R T\right)
$$

Similarly to refractive index, the density shows an inverse correlation where it decreases when the temperature increases (Fig. 6). In addition, density values measured for this DES are close two or three-fold higher of that found for the aforementioned organic solvents. ${ }^{60}$

The variation of density with temperature was modelled according to eqn (3), where $\rho$ is the density, $t$ is the temperature, $a$ and $b$ are constants (Table 1 ).

$$
\rho\left(\mathrm{g} \mathrm{cm}^{-3}\right)=a\left(t /{ }^{\circ} \mathrm{C}\right)+b
$$

Gano et $a l .{ }^{53}$ have also studied the effect of temperature on some basic physical properties of the synthesized DES finding that the viscosity, density and refractive index decrease with temperature, while the conductivity increased with temperature. Our observations are in agreement with the pervious study and allow to predict the behaviour of the DES at different temperatures within the studied range $\left(30\right.$ to $\left.80{ }^{\circ} \mathrm{C}\right)$.

The redox properties of the $\mathrm{SnCl}_{2} \cdot 2 \mathrm{H}_{2} \mathrm{O} / \mathrm{ChCl}$ DES were also studied by cyclic voltammetry. Solvents and electrolytes for electrochemical cells should resist a possible oxidation and reduction. The electrochemical potential window (EPW) is an indicator of electrochemical stability of DES and the potential redox of a given analyte in a reaction process involving DES is expected to fall within the EPW. The EPW is also useful in the selection of a DES as an electrochemical solvent for specific electrochemical applications. In this work, we determine the potential window of the DES employing four working electrodes. Results are shown in Table 2.

Anodic and cathodic limits of the EPW were determined with the oxidation current onset potential for chlorine gas evolution and the reduction current onset potential for tin deposition respectively. Although all systems show relatively narrow potential ranges, these results are consistent with the behaviours of similar systems previously reported. ${ }^{61,62}$ All this indicates that the $\mathrm{SnCl}_{2} \cdot 2 \mathrm{H}_{2} \mathrm{O} / \mathrm{ChCl}$ DES can be a good

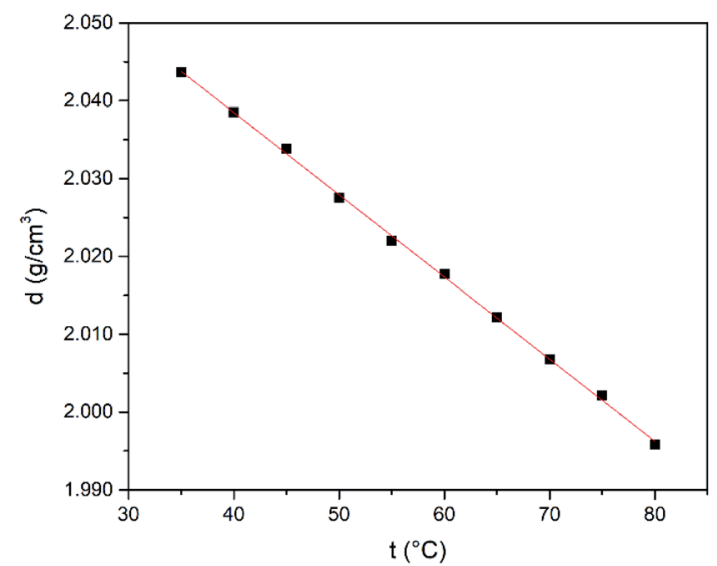

Fig. 6 Density as a function of temperature for the $\mathrm{SnCl}_{2} \cdot 2 \mathrm{H}_{2} \mathrm{O} / \mathrm{ChCl}$ DES. 
Table 2 Potential window for the $\mathrm{SnCl}_{2} \cdot 2 \mathrm{H}_{2} \mathrm{O} / \mathrm{ChCl}$ DES

\begin{tabular}{llll}
\hline Working electrode & $\begin{array}{l}\text { Anodic limit } \\
(\mathrm{V})\end{array}$ & $\begin{array}{l}\text { Cathodic limit } \\
(\mathrm{V})\end{array}$ & $\begin{array}{l}\text { Potential window } \\
(\mathrm{V})\end{array}$ \\
\hline Glassy carbon & 2 & -0.4 & 2.4 \\
$\mathrm{Pt}$ & 2 & -0.3 & 2.3 \\
$\mathrm{Au}$ & 0.5 & -0.3 & 0.8 \\
$\mathrm{Sn}$ & 1.9 & -0.4 & 2.3
\end{tabular}

electrochemical solvent for applications in electroanalytical chemistry and electrosynthesis.

The use of DES as a novel solvent in reduction reactions is another application field that we explored. In order to demonstrate the reduction ability of the DES, the electrochemical properties for a model reaction were examined by cyclic voltammetry (CV) mixing $10 \mathrm{mM}$ of nitrobenzene in $\mathrm{SnCl}_{2} \cdot 2 \mathrm{H}_{2} \mathrm{O} /$
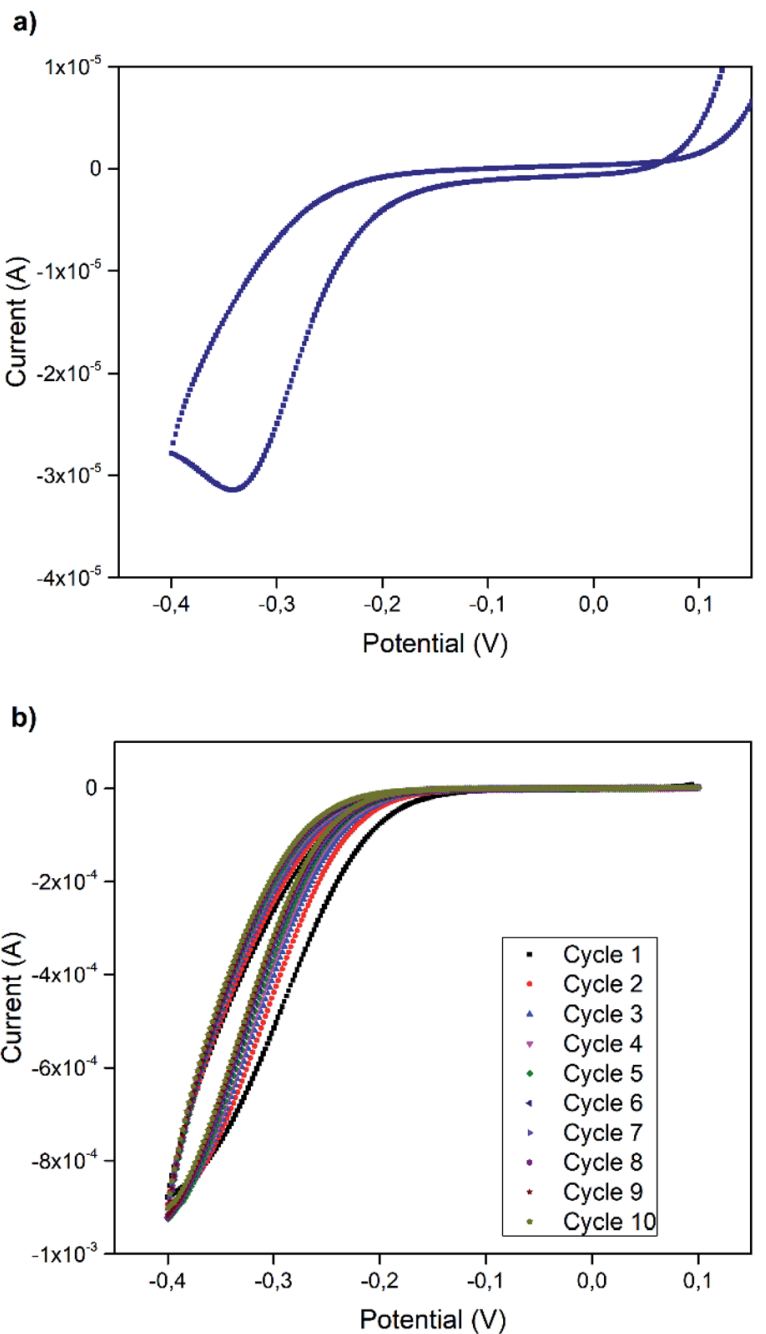

Fig. 7 Cyclic voltammograms of nitrobenzene $(10 \mathrm{mM})$; in $\mathrm{SnCl}_{2}$ $\cdot 2 \mathrm{H}_{2} \mathrm{O} / \mathrm{ChCl}$ DES at scan rate $100 \mathrm{mV} \mathrm{s}^{-1}$ using $\mathrm{GC}$ disc versus $\mathrm{Ag} / \mathrm{AgCl}$ as reference electrode and Pt wire counter electrode at $60{ }^{\circ} \mathrm{C}$. (a) Recorded after adding nitrobenzene; (b) ten cycles, recorded one minute after nitrobenzene was added.
ChCl mixture and glassy carbon (GC) as working electrode (Fig. 7).

Fig. 7a displays the cyclic voltammogram recorded immediately after adding nitrobenzene to the mixture. Here, only one irreversible cathodic peak at $-0.35 \mathrm{~V}$ is observed, which most likely corresponds to the reduction of nitrobenzene to aniline. Fig. 7b shows the voltammograms recorded one minute after the addition of nitrobenzene to the mixture, and the absence of reduction peak of nitrobenzene to aniline suggests that the reduction in homogeneous phase by the action of the DES components occurs very fast. The kinetic studies of this process will be presented in a future work.

With the results of the electrochemical characterization in our hands, we study the reduction of several aromatic nitrocompounds employing the eutectic mixture as solvent and reducing agent (Table 3). As seen in Table 3, all mononitroaromatic compounds are effectively reduced in very short reaction times. Electron-donating and electron-withdrawing groups does not influence the outcome of the reaction and the corresponding anilines 1a-6a, 10a-16a are obtained in excellent yields. The tolerance of ketone and ester functionalities is demonstrated in the reduction of $p$-nitroacetophenone 15 and methyl 4-nitrobenzoate 16 which yields $p$-aminoacetophenone 15a and methyl 4-aminobenzoate 16a in 93 and 90\% yield respectively. In addition, dinitrobenzene isomers 7-9 also afforded the target diaminobenzenes (entries 7 to 9) in yields comparable to that of the mononitro analogues (entries 4 to 6).

Reactions performed at low temperatures $\left(40\right.$ and $\left.60{ }^{\circ} \mathrm{C}\right)$ also afford the desired products in longer reaction times (between 35

Table 3 Reduction of nitroaromatic compounds in tin(॥) chloride dihydrate/choline chloride $\mathrm{DES}^{a}$

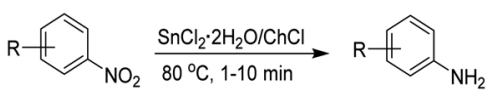

\begin{tabular}{llllll}
\hline Entry & Compd & $\mathrm{R}$ (nitrocompd) & Compd & $\mathrm{R}$ (aniline) & Yield $^{b}$ \\
\hline 1 & $\mathbf{1}$ & $\mathrm{H}$ & $\mathbf{1 a}$ & $\mathrm{H}$ & 96 \\
2 & $\mathbf{2}$ & $o-\mathrm{OH}$ & $\mathbf{2 a}$ & $o-\mathrm{OH}$ & 94 \\
3 & $\mathbf{3}$ & $p-\mathrm{OH}$ & $\mathbf{3 a}$ & $p-\mathrm{OH}$ & 93 \\
4 & $\mathbf{4}$ & $o-\mathrm{NH}_{2}$ & $\mathbf{4 a}$ & $o-\mathrm{NH}_{2}$ & 96 \\
5 & $\mathbf{5}$ & $m-\mathrm{NH}_{2}$ & $\mathbf{5 a}$ & $m-\mathrm{NH}_{2}$ & 95 \\
6 & $\mathbf{6}$ & $p-\mathrm{NH}_{2}$ & $\mathbf{6 a}$ & $p-\mathrm{NH}_{2}$ & 96 \\
7 & 7 & $o-\mathrm{NO}_{2}{ }^{c}$ & $\mathbf{4 a}$ & $o-\mathrm{NH}_{2}$ & 94 \\
8 & $\mathbf{8}$ & $m-\mathrm{NO}_{2}{ }^{c}$ & $\mathbf{5 a}$ & $m-\mathrm{NH}_{2}$ & 93 \\
9 & $\mathbf{9}$ & $p-\mathrm{NO}_{2}{ }^{c}$ & $\mathbf{6 a}$ & $p-\mathrm{NH}_{2}$ & 94 \\
10 & $\mathbf{1 0}$ & $o-\mathrm{Me}$ & $\mathbf{1 0 a}$ & $o-\mathrm{Me}$ & 97 \\
11 & $\mathbf{1 1}$ & $m-\mathrm{Me}$ & $\mathbf{1 1 a}$ & $m-\mathrm{Me}$ & 96 \\
12 & $\mathbf{1 2}$ & $p-\mathrm{Me}$ & $\mathbf{1 2 a}$ & $p-\mathrm{Me}$ & 94 \\
13 & $\mathbf{1 3}$ & $p-\mathrm{Cl}$ & $\mathbf{1 3 a}$ & $p-\mathrm{Cl}$ & 95 \\
14 & $\mathbf{1 4}$ & $p-\mathrm{Br}$ & $\mathbf{1 4 a}$ & $p-\mathrm{Br}$ & 98 \\
15 & $\mathbf{1 5}$ & $p-(\mathrm{CO}) \mathrm{CH}_{3}$ & $\mathbf{1 5 a}$ & $p-(\mathrm{CO}) \mathrm{CH}_{3}$ & 93 \\
16 & $\mathbf{1 6}$ & $p-\mathrm{CO}{ }_{2} \mathrm{CH}_{3}$ & $\mathbf{1 6 a}$ & $p-\mathrm{CO} \mathrm{CH}_{3}$ & 90
\end{tabular}

${ }^{a}$ Reaction conditions: nitroaromatic compound $(1 \mathrm{mmol}), 1.6 \mathrm{~g}$ of $\mathrm{SnCl}_{2} \cdot 2 \mathrm{H}_{2} \mathrm{O} / \mathrm{ChCl}\left(2: 1\right.$ molar ratio) DES, $80{ }^{\circ} \mathrm{C}, 1-10 \mathrm{~min} .{ }^{b}$ Isolated yield. ${ }^{c} 3.2 \mathrm{~g}$ of $\mathrm{SnCl}_{2} \cdot 2 \mathrm{H}_{2} \mathrm{O} / \mathrm{ChCl}$ DES was used. 
minutes to one hour) due to the increased viscosity of the DES and lower solubility of nitroarenes. The reaction conditions here established allow the reduction of a wide variety of nitroarenes employing a simple experimental setup with shorter reaction times in comparison to traditional methods reported with stannous chloride. ${ }^{63,64}$ In light of these interesting results, we decided to explore the synthesis of some $N$-arylacetamides through a one-pot reductive-acetylation of nitroarenes employing the DES. To perform this synthetic transformation starting from nitroaromatic compounds, several combination of reagents such as red phosphorus, iodine and carboxylic acids, ${ }^{65}$ platinum complexes/carboxylic acids, ${ }^{66}$ platinum nanoparticles, ${ }^{67}$ magnetic copper ${ }^{68}$ and nickel ${ }^{69}$ catalyst with acetic anhydride have been reported. In our model reaction, nitrobenzene reacted with acetic anhydride in presence of the DES affording acetanilide in $92 \%$ yield (Table 4 entry 1 ). Other nitroarenes also reacted smoothly yielding the corresponding

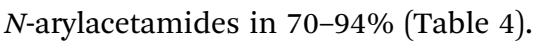

As seen in Table 4, nitroaromatic compounds 10-14 bearing methyl and halogen substituents afforded the corresponding acetanilides 10b-14b in good yields. On the other hand, bisacetylated compounds $\mathbf{2 b}, \mathbf{3 b}, \mathbf{8 b}$ and $\mathbf{9 b}$ were obtained with nitroarenes bearing amino and hydroxy groups (Table 4, entries 2-5). Any attempts to selectively achieve the acetylation on the amino over the hydroxy group in the reaction of compounds 2 and 3 were unsuccessful.

To further expand the scope of applications for the $\mathrm{SnCl}_{2}$ $\cdot 2 \mathrm{H}_{2} \mathrm{O} / \mathrm{ChCl}$ DES, our synthetic efforts were next directed toward the obtention of indolo(pyrrolo)[1,2-a]quinoxalines. Different synthetic strategies for the construction of this heterocyclic skeleton are depicted in Scheme 1, however the development of a simple and efficient synthetic methodology involving readily available starting materials, few synthetic

Table 4 One-pot reductive acetylation of nitroarenes in tin(॥) chloride dihydrate/choline chloride $\mathrm{DES}^{a}$

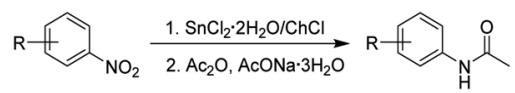

\begin{tabular}{llllll} 
Entry & Compd & $\mathrm{R}$ (nitrocompd) & compd & $\mathrm{R}$ (acetaniline) & Yield $^{b}$ \\
\hline 1 & $\mathbf{1}$ & $\mathrm{H}$ & $\mathbf{1 b}$ & $\mathrm{H}$ & 92 \\
2 & $\mathbf{2}$ & $o-\mathrm{OH}^{c}$ & $\mathbf{2 b}$ & $o$-OAc & 70 \\
3 & $\mathbf{3}$ & $p-\mathrm{OH}^{c}$ & $\mathbf{3 b}$ & $p$-OAc & 89 \\
4 & $\mathbf{8}$ & $m-\mathrm{NO}_{2}{ }^{d}$ & $\mathbf{8 b}$ & $m-\mathrm{NHAc}$ & 88 \\
5 & $\mathbf{9}$ & $p-\mathrm{NO}_{2}{ }^{d}$ & $\mathbf{9 b}$ & $p-\mathrm{NHAc}$ & 91 \\
6 & $\mathbf{1 0}$ & $o-\mathrm{Me}$ & $\mathbf{1 0 b}$ & $o-\mathrm{Me}$ & 87 \\
7 & $\mathbf{1 1}$ & $m-\mathrm{Me}$ & $\mathbf{1 1 b}$ & $m-\mathrm{Me}$ & 89 \\
8 & $\mathbf{1 2}$ & $p-\mathrm{Me}$ & $\mathbf{1 2 b}$ & $p-\mathrm{Me}$ & 93 \\
9 & $\mathbf{1 3}$ & $p-\mathrm{Cl}$ & $\mathbf{1 3 b}$ & $p-\mathrm{Cl}$ & 94 \\
10 & $\mathbf{1 4}$ & $p-\mathrm{Br}$ & $\mathbf{1 4 b}$ & $p-\mathrm{Br}$ & 92
\end{tabular}

${ }^{a}$ Reaction conditions: nitroaromatic compound $(1 \mathrm{mmol}), 1.6 \mathrm{~g}$ of $\mathrm{SnCl}_{2} \cdot 2 \mathrm{H}_{2} \mathrm{O} / \mathrm{ChCl}\left(2: 1\right.$ molar ratio) DES, $80{ }^{\circ} \mathrm{C}, 1-10$ min, then $\mathrm{Ac}_{2} \mathrm{O}$ $(1.2 \mathrm{mmol}), \mathrm{AcONa} \cdot 3 \mathrm{H}_{2} \mathrm{O}(2 \mathrm{mmol}), \mathrm{H}_{2} \mathrm{O}(1 \mathrm{~mL}) 10 \mathrm{~min} .{ }^{b}$ Isolated yield. ${ }^{c} 2.4 \mathrm{mmol}$ of $\mathrm{Ac}_{2} \mathrm{O}$, and $4 \mathrm{mmol} \mathrm{AcONa} \cdot 3 \mathrm{H}_{2} \mathrm{O}$ were used. ${ }^{d} 3.2 \mathrm{~g}$ of $\mathrm{SnCl}_{2} \cdot 2 \mathrm{H}_{2} \mathrm{O} / \mathrm{ChCl} \mathrm{DES}, 2.4 \mathrm{mmol}$ of $\mathrm{Ac}_{2} \mathrm{O}$, and $4 \mathrm{mmol}$ AcONa $\cdot 3 \mathrm{H}_{2} \mathrm{O}$ were used. steps and high yields of products is highly desirable. Therefore, we envisaged that the reaction of aldehydes with the nitroarene 17 or 18, which are easily obtained in one step from $o$-nitroaniline $^{70}$ and $o$-fluoronitrobenzene ${ }^{42}$ respectively, might be a suitable synthetic proposal to obtain the target quinoxalines (Scheme 2). To develop our proposal, we first synthesized the nitroarene 17 starting from $o$-nitroaniline and dimethoxytetrahydrofurane following the methods reported in literature ${ }^{70}$ (Scheme 2), and the reaction between compound 17 and benzaldehyde in $\mathrm{SnCl}_{2} \cdot 2 \mathrm{H}_{2} \mathrm{O} / \mathrm{ChCl}$ DES was taken as model reaction.

Initially, equimolar amounts of $\mathbf{1 7}$ and benzaldehyde ( $1 \mathrm{mmol}$ each) were poured into the DES $\left(2.0 \mathrm{~g}, 1.53 \mathrm{~g} \mathrm{SnCl}_{2}\right.$ $\cdot 2 \mathrm{H}_{2} \mathrm{O}$ and $0.47 \mathrm{~g} \mathrm{ChCl}$ ) and the reaction was conducted at 80 and $110{ }^{\circ} \mathrm{C}$ obtaining the pyrrolo[1,2-a]quinoxaline $17 \mathbf{a}$ in 75 and $92 \%$ yield after 1 hour and 30 minutes respectively. Reactions performed with tin(II) chloride $(1.53 \mathrm{~g}, 6.8 \mathrm{mmol})$ under solvent free conditions $\left(110^{\circ} \mathrm{C}, 30 \mathrm{~min}\right)$ and employing ethyl acetate as solvent ( $3 \mathrm{~h}$, reflux) showed that the heterocyclic compound was not formed in the first case, and a $45 \%$ yield was obtained in the second experiment. In addition, a reduction on the amount of the DES $(1.0 \mathrm{~g}$ of DES containing $763 \mathrm{mg}$, $3.4 \mathrm{mmol}$ of tin(II) chloride) decreases the yield to $38 \%$. These results show that under the optimal reaction conditions ( $2 \mathrm{~g}$ of DES, $110{ }^{\circ} \mathrm{C}, 30$ minutes) the target compound can be obtained in a good yield, and to identify the benefits and limitations of our method, we began exploring the substrate scope by reacting different aliphatic and aromatic aldehydes. Results are summarized in Table 5.

According to Table 5, all aromatic aldehydes bearing electron-donating and electron-withdrawing groups reacted easily with the nitroarene $\mathbf{1 7}$ affording the corresponding pyrrolo[1,2-a]quinoxalines $\mathbf{1 7 a - 1 7 k}$ in $75-98 \%$ yield. No clear tendency was observed regarding the influence of the substitution pattern or electronic character of the groups on the aromatic ring (Table 5, entries 1-9). Heteroaromatic and aliphatic aldehydes such as 2-pyridinecarboxaldehyde and $n$ decanal also provide the corresponding derivatives $\mathbf{1 7} \mathbf{j}$ and $\mathbf{1 7} \mathbf{k}$ in satisfactory yields (Table 5, entries 10 and 11).

Once the series of pyrrolo[1,2-a]quinoxalines were obtained, we focused on the synthesis of the indolo[1,2- $a]$ quinoxalines, and for this, the nitroarene $\mathbf{1 8}$ was successfully prepared from $o$ fluoronitrobenzene and indole. ${ }^{42}$ Next, compound 18 reacted with different aldehydes affording the desired compounds 18a-

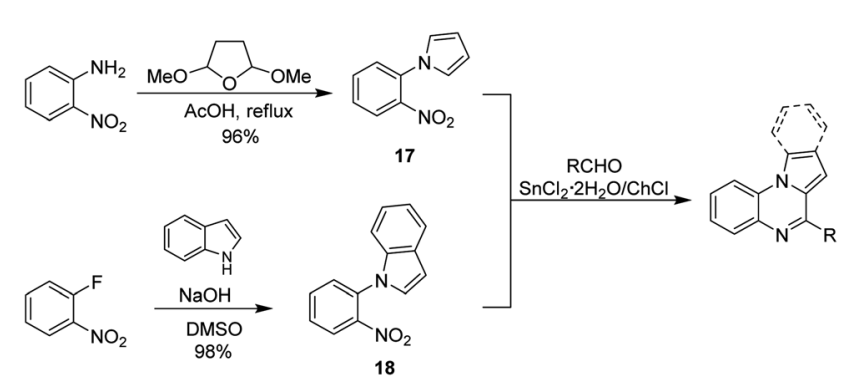

Scheme 2 Synthetic proposal for the obtention of indolo(pyrrolo)[1,2a]quinoxalines. 
Table 5 Substrate scope for the synthesis of indolo(pyrrolo)[1,2-a] quinoxalines in tin(॥) chloride dihydrate/choline chloride DES ${ }^{a}$

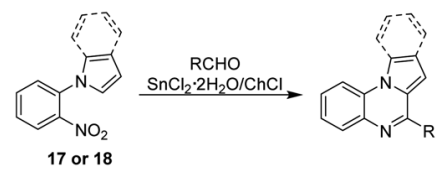

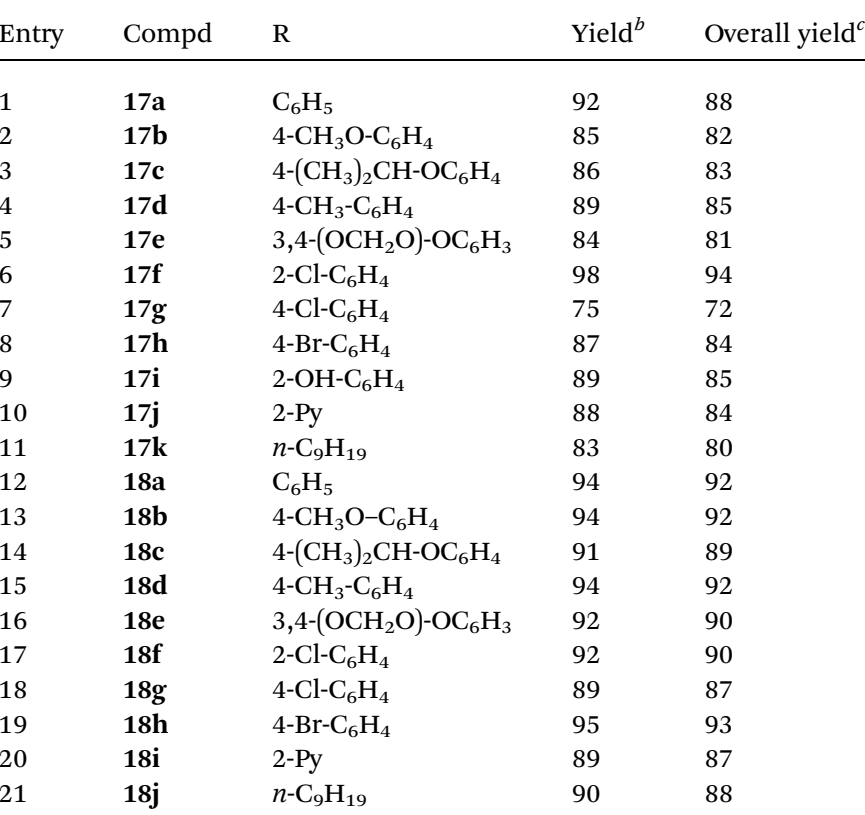

${ }^{a}$ Reaction conditions: compound 17 or 18 (1 mmol), aldehyde ( 1 mmol), $2.0 \mathrm{~g}$ of $\mathrm{SnCl}_{2} \cdot 2 \mathrm{H}_{2} \mathrm{O} / \mathrm{ChCl}\left(2: 1\right.$ molar ratio) DES, $110{ }^{\circ} \mathrm{C}$, 30 min. ${ }^{b}$ Isolated yield. ${ }^{c}$ Calculated considering the yield for compounds 17 and 18.

18j in $89-95 \%$ yield (Table 5). As expected, similar results for the reactivity were observed in comparison to the pyrroloquinoxaline series: the reaction of aromatic and heteroaromatic aldehydes with 18 in the presence of the DES leads to the formation of compounds 18a-18i in good to excellent yields (Table 5, entries 12 to 20 ), and $n$-decanal yield the corresponding product $18 \mathrm{j}$ in $90 \%$ yield (Table 5 , entry 21 ).

To evaluate the synthetic efficiency of the method here developed, the overall yield for each synthesized compound was calculated. As shown in Table 5, the first group of derivatives corresponding to pyrrolo[1,2-a]quinoxalines $\mathbf{1 7} \mathbf{a}-\mathbf{1 7} \mathbf{j}$, was obtained in $72-94 \%$ overall yields, while for the second group of indolo[1,2-a]quinoxalines 18a-18j a $87-92 \%$ overall yield was achieved. These remarkable results are attributed to two factors: the few synthetic steps involved (two for both series of compounds starting from inexpensive and commercially available reagents) and the good to excellent yields obtained in each step.

To evaluate if the DES also plays a role as catalyst in the reaction, and to propose a plausible reaction mechanism two control experiments were performed (Scheme 3).

For the first experiment, the amine 19 and benzaldehyde were poured into the DES and the reaction was run under the

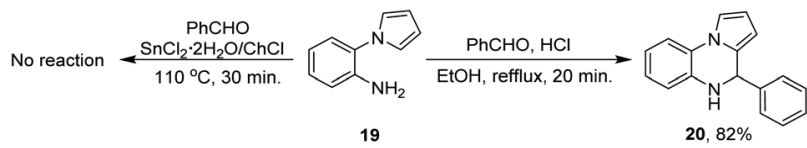

Scheme 3 Control experiments performed to propose a plausible reaction mechanism.

optimal reaction conditions already established, however the compound 17a was not obtained. Taking into account that $\mathrm{HCl}$ might be formed during the reaction of compounds $\mathbf{1 7}$ and $\mathbf{1 8}$ with the DES, the second experiment was run with the amine 19, benzaldehyde and $\mathrm{HCl}$ (drops) in ethanol. After 30 minutes, the dihydroquinoxaline 20 was obtained in $82 \%$ yield.

Control experiments demonstrate that although the deep eutectic solvent promotes a fast reduction of the nitro group, it does not catalyze the cyclization process, and therefore the DES plays a dual role as solvent and reducing agent. On the other hand, it is hypothesized that the cyclization step might be promoted by hydrochloric acid generated in situ in the reaction medium in which the dihydroquinoxaline $\mathbf{2 0}$ undergo an aerobic oxidation.

With the experimental results previously obtained, a plausible reaction mechanism for the obtention of compound $\mathbf{1 7 a}$ is proposed in Scheme 4. As depicted in Scheme 4, the reaction begins with the reduction of the nitroarene $\mathbf{1 7}$ mediated by the $\mathrm{SnCl}_{2} \cdot 2 \mathrm{H}_{2} \mathrm{O}$ present in the DES affording the corresponding amino derivative 19. It is known that the reduction of nitro groups might involve the formation of several intermediates, however the precise mechanism still remains unclear. ${ }^{71}$ Next, the reaction of the intermediate amine 19 with benzaldehyde (activated by $\mathrm{HCl}$ ) leads to the formation of the imine 21 which follows an intramolecular cyclization promoted by the nucleophilic attack of the carbon C-1 of the pyrrole core over the azomethine carbon of $\mathbf{2 1}$ affording the dihydroquinoxaline $\mathbf{2 0}$ which after an aerobic oxidation yield the corresponding pyrrolo[1,2-a]quinoxaline $\mathbf{1 7 a}$.

Finally, gram scale experiments $(10 \mathrm{mmol})$ for the obtention of compounds $1 \mathrm{a}, \mathbf{1 b}$ and $17 \mathbf{a}$ were conducted in order to demonstrate the versatility of this synthetic method. As result of these experiments, the target compounds were obtained in 90 , 87 and $85 \%$ yield respectively.

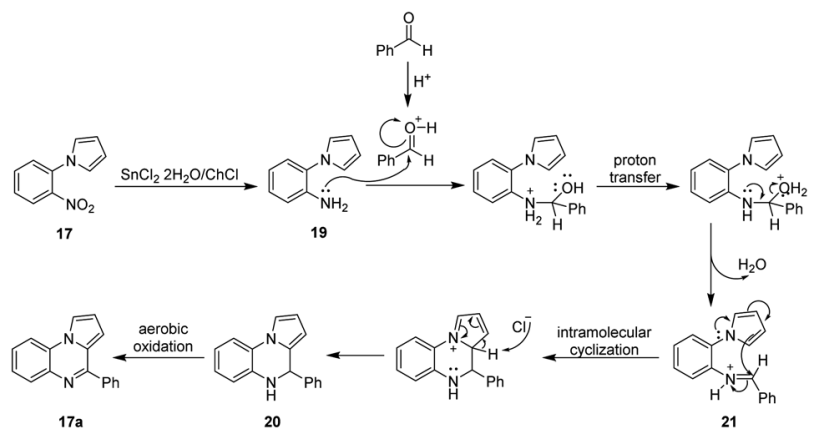

Scheme 4 Plausible reaction mechanism for the obtention of compound 17 a 


\section{Experimental}

\section{Materials and methods}

All the chemicals and solvents were purchased from commercial suppliers (Aldrich, Merck). Melting points, reported without correction, were measured using a Stuart SMP10 apparatus. The FT-IR spectra were obtained with a Shimadzu IR prestige 21 spectrophotometer (Columbia, MD, USA). ${ }^{1} \mathrm{H}$ and ${ }^{13} \mathrm{C}$ NMR spectra were recorded with a Bruker AVANCE III system operating at $400 \mathrm{MHz}$, using residual and deuterated solvent peaks of $\mathrm{CDCl}_{3}\left(\delta_{\mathrm{H}} 7.26 ; \delta_{\mathrm{C}} 77.0\right)$ and DMSO $\left(\delta_{\mathrm{H}} 2.50 ; \delta_{\mathrm{C}} 39.5\right)$ as reference standards. Elemental analyses were performed on a Thermo Scientific Flash 2000 CHNS/O analyser and their results agreed with the calculated values. Raman spectra was acquired with Thermo Scientific DXR Raman Microscope, excitation was accomplished by using a single line of $780 \mathrm{~nm}$ wavelength from a frequency-stabilized single mode diode laser. The incident power was about $20 \mathrm{~mW}$ at the sample point. The density of the DES was measured using a liquid densitometer (Anton Paar DMA4500M). An Abbe type refractometer (model 2WAJ equipped with a sodium D1 line) was used to measure the DES refractive. The conductivity and its temperature dependence were determined using a Jenway 470 portable conductivity/TDS meter calibrated by measuring the conductivities of aqueous solutions of $\mathrm{KCl}$ at different concentrations. The variation of the temperature for the determination of the physical properties was done by using a Lauda Alpha water circulator. Cyclic voltammetry was carried out using a Gamry Interface $1000 \mathrm{E}$ potentiostat from Gamry Instruments. The electrochemical measurements were performed in a conventional three-electrode cell, with the $0.071 \mathrm{~cm}^{2}$ Glassy Carbon, the $0.0314 \mathrm{~cm}^{2} \mathrm{Au}$, the $0.0314 \mathrm{~cm}^{2} \mathrm{Pt}$, and $0.0314 \mathrm{~cm}^{2}$ Sn disks as the working electrodes, $\mathrm{Ag} / \mathrm{AgCl}$ as the reference electrode, and Pt wire as the counter electrode. The working electrodes were polished with 1 and $0.3 \mu \mathrm{m} \gamma$-alumina paste, rinsed and sonicated for two minutes with deionized water, and dried prior to all measurements. The experiments were performed at $60{ }^{\circ} \mathrm{C}$ using a scan rate of $100 \mathrm{mV} \mathrm{s}^{-1}$.

\section{General experimental procedure for the synthesis of} compounds 1a-6a, 10a-16a

To an open headspace vial equipped with a magnetic stir bar, the nitroarene $(1.0 \mathrm{mmol})$ and $1.6 \mathrm{~g}$ of $\mathrm{SnCl}_{2} \cdot 2 \mathrm{H}_{2} \mathrm{O} / \mathrm{ChCl}$ DES were added, and the resulting solution was then stirred and heated at $80{ }^{\circ} \mathrm{C}$. After running the reaction to an appropriate time (TLC analysis), the mixture was cooled to room temperature, neutralized with $\mathrm{NaHCO}_{3}$ and extracted with AcOEt $(3 \times 10$ $\mathrm{mL}$ ). After drying over anhydrous $\mathrm{Na}_{2} \mathrm{SO}_{4}$ and evaporating the solvent under reduced pressure, the desired product was obtained in high purity without further purification.

p-Aminophenol (3a). Beige solid, mp $187-189{ }^{\circ} \mathrm{C}$. Yield: $93 \%$. ${ }^{1} \mathrm{H}$ NMR (400 MHz, DMSO-d 6 ) $\delta$ (ppm): 8.49 (brs, 1H), 6.50 (d, $J$ $=8.8,2 \mathrm{H}), 6.43(\mathrm{~d}, J=8.8,2 \mathrm{H}), 4.38\left(\mathrm{br} \mathrm{s}, 2 \mathrm{H},-\mathrm{NH}_{2}\right) .{ }^{13} \mathrm{C} \mathrm{NMR}$ (100 MHz, DMSO-d ${ }_{6}$ ) $\delta$ (ppm): 148.7, 141.1, 116.2, 115.7.

p-Toluidine (12a). White solid, mp $41-43{ }^{\circ} \mathrm{C}$. Yield $94 \% .{ }^{1} \mathrm{H}$ NMR (400 MHz, $\left.\mathrm{CDCl}_{3}\right) \delta(\mathrm{ppm}): 7.04(\mathrm{~d}, J=7.5 \mathrm{~Hz}, 2 \mathrm{H}), 6.67$ (d,
$J=6.7 \mathrm{~Hz}, 2 \mathrm{H}), 3.56\left(\mathrm{~s}, 2 \mathrm{H},-\mathrm{NH}_{2}\right), 2.32(\mathrm{~s}, 3 \mathrm{H}) \mathrm{ppm} .{ }^{13} \mathrm{C} \mathrm{NMR}$ $\left(100 \mathrm{MHz}, \mathrm{CDCl}_{3}\right) \delta(\mathrm{ppm}): 143.9,129.8,127.8,115.3,20.5$.

\section{General experimental procedure for the synthesis of $\mathrm{N}$ -} arylacetamides $1 b-3 b, 8 b-14 b$

To an open headspace vial equipped with a magnetic stir bar, the nitroarene $(1.0 \mathrm{mmol})$ and $1.6 \mathrm{~g}$ of $\mathrm{SnCl}_{2} \cdot 2 \mathrm{H}_{2} \mathrm{O} / \mathrm{ChCl}(2: 1$ molar ratio) DES were added, and the resulting solution was then stirred and heated at $80^{\circ} \mathrm{C}$. After complete reduction of the nitroarene (TLC), $\mathrm{Ac}_{2} \mathrm{O}(1.2 \mathrm{mmol})$ and $\mathrm{AcONa} \cdot 3 \mathrm{H}_{2} \mathrm{O}(2.0 \mathrm{mmol})$ in $2 \mathrm{~mL}$ water were added and heating was continued until the reaction was complete (TLC analysis). Next, the reaction mixture was cooled to room temperature, neutralized with $\mathrm{NaHCO}_{3}$ and extracted with AcOEt $(3 \times 10 \mathrm{~mL})$. After drying over anhydrous $\mathrm{Na}_{2} \mathrm{SO}_{4}$ and evaporating the solvent under reduced pressure, the crude material was purified by column chromatography on silica gel to afford the desired product.

$\boldsymbol{N}$-Phenylacetamide (1b). Light yellow solid, mp 112-114 ${ }^{\circ} \mathrm{C}$. Yield: $92 \% .{ }^{1} \mathrm{H}$ NMR (400 $\mathrm{MHz}, \mathrm{CDCl}_{3}$ ) $\delta$ (ppm): 8.24 (brs, $1 \mathrm{H}$ ), $7.54(\mathrm{~d}, J=7.2 \mathrm{~Hz}, 2 \mathrm{H}), 7.32-7.28(\mathrm{~m}, 2 \mathrm{H}), 7.12-7.08(\mathrm{~m}, 1 \mathrm{H})$, 2.16 (s, 3H). ${ }^{13} \mathrm{C}$ NMR (100 MHz, $\left.\mathrm{CDCl}_{3}\right) \delta$ (ppm): 169.1, 138.1, 128.9, 124.2, 120.2, 24.4.

$\boldsymbol{N}$-(4-Bromophenyl)acetamide (14b). Light beige solid, mp 166-169 ${ }^{\circ}$ C. Yield: 92\%. ${ }^{1} \mathrm{H}$ NMR (400 MHz, $\mathrm{CDCl}_{3}+\mathrm{DMSO}_{6}$ ) $\delta$ (ppm): 9.37 (br s, 1H), 7.40 (d, $J=6.3 \mathrm{~Hz}, 2 \mathrm{H}), 7.29$ (d, $J=$ $6.0 \mathrm{~Hz}, 2 \mathrm{H}), 2.05(\mathrm{~s}, 3 \mathrm{H}) .{ }^{13} \mathrm{C} \mathrm{NMR}\left(100 \mathrm{MHz}, \mathrm{CDCl}_{3}+\mathrm{DMSO}_{6}\right.$ ) $\delta$ (ppm): 169.0, 138.1, 131.5, 121.3, 115.6, 24.2.

\section{General experimental procedure for the synthesis of indolo(pyrrolo) $[1,2-a]$ quinoxalines $17 \mathrm{a}-\mathrm{k}$ and $18 \mathrm{a}-\mathrm{j}$}

To an open headspace vial equipped with a magnetic stir bar, the nitroarene 17 or $18(1.0 \mathrm{mmol})$, the corresponding aldehyde ( $1 \mathrm{mmol}$ ) and $2.0 \mathrm{~g}$ of $\mathrm{SnCl}_{2} \cdot 2 \mathrm{H}_{2} \mathrm{O} / \mathrm{ChCl}(2: 1$ molar ratio) DES were added, and the resulting solution was then stirred and heated at $110{ }^{\circ} \mathrm{C}$. After running the reaction to an appropriate time (TLC analysis), the mixture was allowed to cool to room temperature, neutralized with $\mathrm{NaHCO}_{3}$ and extracted with AcOEt $(3 \times 10 \mathrm{~mL})$. After drying over anhydrous $\mathrm{Na}_{2} \mathrm{SO}_{4}$ and evaporating the solvent under reduced pressure, the crude material was purified by column chromatography on silica gel to afford the desired product.

4-Phenylpyrrolo[1,2-a]quinoxaline (17a). Yellow solid, mp 116-119 ${ }^{\circ} \mathrm{C}$. Yield: 92\%. ${ }^{1} \mathrm{H}$ NMR (400 MHz, $\left.\mathrm{CDCl}_{3}\right) \delta(\mathrm{ppm})$ : 8.11-8.04 (m, 3H), 7.86 (s, 1H), 7.71 (d, J=2.8 Hz, 1H), 7.59-7.56 $(\mathrm{m}, 3 \mathrm{H}), 7.41(\mathrm{~s}, 2 \mathrm{H}), 6.99(\mathrm{~d}, J=4.0 \mathrm{~Hz}, 1 \mathrm{H}), 6.82(\mathrm{~d}, J=2.6 \mathrm{~Hz}$, 1H). ${ }^{13} \mathrm{C} \mathrm{NMR}\left(100 \mathrm{MHz}, \mathrm{CDCl}_{3}\right) \delta$ (ppm): 154.2, 138.4, 136.1, $130.0,129.8,128.7,128.6,127.4$, 127.0, 125.2, 125.2, 114.7, 114.0, 113.6, 108.7. Anal. calcd for $\mathrm{C}_{17} \mathrm{H}_{12} \mathrm{~N}_{2}$ : C, 83.58; $\mathrm{H}$, 4.95; N, 11.47. Found: C, 83.60; H, 4.91; N, 11.49.

6-(4-Methoxyphenyl)indolo[1,2-a]quinoxaline (18b). Red solid, mp 165-167 ${ }^{\circ} \mathrm{C} .{ }^{1} \mathrm{H}$ NMR (400 MHz, $\left.\mathrm{CDCl}_{3}\right) \delta$ (ppm): 8.49 $(\mathrm{dd}, J=15.8,10.0 \mathrm{~Hz}, 1 \mathrm{H}), 8.14(\mathrm{~d}, J=8.5 \mathrm{~Hz}, 1 \mathrm{H}), 7.86$ (d, $J=$ $8.5 \mathrm{~Hz}, 1 \mathrm{H}), 7.71(\mathrm{~d}, J=6.4 \mathrm{~Hz}, 1 \mathrm{H}), 7.64(\mathrm{~d}, J=8.7 \mathrm{~Hz}, 1 \mathrm{H}), 7.58$ $(\mathrm{m}, 1 \mathrm{H}), 7.15(\mathrm{~d}, J=8.7 \mathrm{~Hz}, 2 \mathrm{H}), 7.03(\mathrm{~d}, J=8.4 \mathrm{~Hz}, 3 \mathrm{H}), 6.70$ (d, $J=1.4 \mathrm{~Hz}, 1 \mathrm{H}), 3.91$ (s, 3H). ${ }^{13} \mathrm{C} \mathrm{NMR}\left(100 \mathrm{MHz} \mathrm{CDCl}_{3}\right) \delta(\mathrm{ppm})$ : 172.9 , 163.0, 134.3, 133.6, 131.9, 131.4, 129.9, 129.4, 128.8, 
127.5, 127.1, 125.2, 123.6, 123.5, 120.8, 115.0, 114.7, 114.4, 114.0, 55.5. Anal. calcd for $\mathrm{C}_{22} \mathrm{H}_{16} \mathrm{~N}_{2} \mathrm{O}: \mathrm{C}, 81.46 ; \mathrm{H}, 4.97 ; \mathrm{N}, 8.64$; $\mathrm{O}$, 4.93. Found: C, 81.45; H, 4.95; N, 8.65.

\section{Conclusions}

In conclusion, we have studied the IR and Raman spectrum, and different physicochemical properties as function of temperature for the $\mathrm{SnCl}_{2} \cdot 2 \mathrm{H}_{2} \mathrm{O} / \mathrm{ChCl}$ DES. The FTIR and Raman spectrum suggest the formation of hydrogen bonds between $\mathrm{ChCl}$ and $\mathrm{SnCl}_{2} \cdot 2 \mathrm{H}_{2} \mathrm{O}$ through $\mathrm{Cl}^{-}$and $\mathrm{OH}$ groups from $\mathrm{ChCl}$ and water molecules from $\mathrm{SnCl}_{2} \cdot 2 \mathrm{H}_{2} \mathrm{O}$. The refractive index and density show an inverse correlation with temperature while the conductivity increases with temperature. The electrochemical characterization the eutectic mixture presents a good potential window, so it could be used as a solvent for electrochemical cells in several types of applications. The eutectic mixture proved to be an effective reducing agent in which several nitroaromatic compounds afforded the corresponding anilines in short reaction times and high yields. In addition, this DES also promoted the reductive-acetylation of nitroarenes yielding acetanilides in 70-94\%. Finally, a simple, fast and high yield method for the synthesis of indolo(pyrrolo) [1,2-a]quinoxalines via one-pot reductive cyclization-oxidation reaction was developed. According with this protocol, the target quinoxalines are obtained in moderate to excellent overall yields in two steps starting form readily available starting materials.

\section{Conflicts of interest}

There are no conflicts to declare.

\section{Acknowledgements}

We gratefully acknowledge the financial support from Universidad Nacional de Colombia. C. O.-P. sincerely thanks Prof. Humberto Zamora for providing some infrastructure facilities. Dedicated to Prof. Dr Burkhard König on the occasion of his 57 th birthday.

\section{Notes and references}

1 K. Masuda, K. Suzuki, A. Ishida-Okawara, S. Mizuno, K. Hotta, S. Miyadoh, O. Hara and M. Koyama, J. Antibiot., 1991, 44, 533-540.

2 R. D. Charan, G. Schlingmann, V. S. Bernan, X. Feng and G. T. Carter, J. Nat. Prod., 2005, 68, 277-279.

3 J.-y. Ueda, J. Hashimoto, A. Nagai, T. Nakashima, H. Komaki, K. Anzai, S. Harayama, T. Doi, T. Takahashi, K. Nagasawa, T. Natsume, M. Takagi and K. Shin-ya, J. Antibiot., 2007, 60, 321-324.

4 K. Kurosawa, K. Takahashi and E. Tsuda, J. Antibiot., 2001, 45, 541-547.

5 D. J. Cole, Pestic. Sci., 1999, 55, 756.

6 J. Cong, X. Yang, J. Liu, J. Zhao, Y. Hao, Y. Wang and L. Sun, Chem. Commun., 2012, 48, 6663-6665.
7 A. M. Faisca Phillips, M. F. C. Guedes da Silva and A. J. L. Pombeiro, Front. Chem., 2020, 8, 30.

8 X. Gu, Y. Dai, T. Guo, A. Franchino, D. J. Dixon and J. Ye, Org. Lett., 2015, 17, 1505-1508.

9 T. Marcelli, R. N. S. van der Haas, J. H. van Maarseveen and H. Hiemstra, Angew. Chem., Int. Ed., 2006, 45, 929-931.

10 M. Orlandi, D. Brenna, R. Harms, S. Jost and M. Benaglia, Org. Process Res. Dev., 2018, 22, 430-445.

11 S. Sobhani, F. O. Chahkamali and J. M. Sansano, RSC Adv., 2019, 9, 1362-1372.

12 M. K. Kolli, P. Elamathi, G. Chandrasekar, V. R. Katta and G. Balvantsinh Raolji, Synth. Commun., 2018, 48, 638-649.

13 D. Yang, D. Fokas, J. Li, L. Yu and C. M. Baldino, Synthesis, 2005, 2005, 47-56.

14 Z. Wu, P. Rea and G. Wickham, Tetrahedron Lett., 2000, 41, 9871-9874.

15 E. J. Hanan, B. K. Chan, A. A. Estrada, D. G. Shore and J. P. Lyssikatos, Synlett, 2010, 2010, 2759-2764.

16 A. H. Romero, J. Salazar and S. E. López, Synthesis, 2013, 45, 2043-2050.

17 A. D. Roy, A. Subramanian and R. Roy, J. Org. Chem., 2006, 71, 382-385.

18 D. I. S. P. Resende, S. Guieu, C. G. Oliva and A. M. S. Silva, Synlett, 2015, 26, 846-850.

19 A. Cho, S. Byun and B. M. Kim, Adv. Synth. Catal., 2018, 360, 1253-1261.

20 A. Patti and S. Pedotti, Tetrahedron, 2010, 66, 5607-5611.

21 R. A. Bunce, B. Nammalwar and L. M. Slaughter, J. Heterocycl. Chem., 2009, 46, 854-860.

22 R. A. Bunce, D. M. Herron, L. B. Johnson and S. V. Kotturi, J. Org. Chem., 2001, 66, 2822-2827.

23 E. Merişor, J. Conrad, I. Klaiber, S. Mika and U. Beifuss, Angew. Chem., Int. Ed., 2007, 46, 3353-3355.

24 M. d. F. Pereira and V. Thiéry, Org. Lett., 2012, 14, 4754-4757.

25 E. Merisor, J. Conrad, S. Mika and U. Beifuss, Synlett, 2007, 2007, 2033-2036.

26 T. Kaushal, G. Srivastava, A. Sharma and A. Singh Negi, Bioorg. Med. Chem., 2019, 27, 16-35.

27 J. A. Pereira, A. M. Pessoa, M. N. D. S. Cordeiro, R. Fernandes, C. Prudêncio, J. P. Noronha and M. Vieira, Eur. J. Med. Chem., 2015, 97, 664-672.

28 K. R. Justin Thomas, M. Velusamy, J. T. Lin, C.-H. Chuen and Y.-T. Tao, Chem. Mater., 2005, 17, 1860-1866.

29 A. P. Kulkarni, Y. Zhu and S. A. Jenekhe, Macromolecules, 2005, 38, 1553-1563.

30 A. Tsami, T. W. Bünnagel, T. Farrell, M. Scharber, S. A. Choulis, C. J. Brabec and U. Scherf, J. Mater. Chem., 2007, 17, 1353-1355.

31 J.-Y. Jaung, Dyes Pigm., 2006, 71, 245-250.

32 M. J. Crossley and L. A. Johnston, Chem. Commun., 2002, 10, 1122-1123.

33 P. P. Castro, G. Zhao, G. A. Masangkay, C. Hernandez and L. M. Gutierrez-Tunstad, Org. Lett., 2004, 6, 333-336.

34 J. L. Sessler, H. Maeda, T. Mizuno, V. M. Lynch and H. Furuta, Chem. Commun., 2002, 8, 862-863.

35 S. K. Dey, M. Al Kobaisi and S. V. Bhosale, ChemistryOpen, 2018, 7, 934-952. 
36 A. A. Kalinin and V. A. Mamedov, Chem. Heterocycl. Compd., 2011, 46, 1423.

37 P. K. Agarwal, D. Sawant, S. Sharma and B. Kundu, Eur. J. Org. Chem., 2009, 2009, 292-303.

38 A. K. Verma, R. R. Jha, V. K. Sankar, T. Aggarwal, R. P. Singh and R. Chandra, Eur. J. Org. Chem., 2011, 2011, 6998-7010.

39 A. Preetam and M. Nath, RSC Adv., 2015, 5, 21843-21853.

40 H.-r. Huo, X.-Y. Tang and Y.-f. Gong, Synthesis, 2018, 50, 2727-2740.

41 J. Li, J. Zhang, H. Yang, Z. Gao and G. Jiang, J. Org. Chem., 2017, 82, 765-769.

42 Z. Zhang, C. Xie, X. Tan, G. Song, L. Wen, H. Gao and C. Ma, Org. Chem. Front., 2015, 2, 942-946.

43 C. Xie, L. Feng, W. Li, X. Ma, X. Ma, Y. Liu and C. Ma, Org. Biomol. Chem., 2016, 14, 8529-8535.

44 H. Liu, F. Zhou, W. Luo, Y. Chen, C. Zhang and C. Ma, Org. Biomol. Chem., 2017, 15, 7157-7164.

45 J. J. Lade, B. N. Patil, M. V. Vhatkar, K. S. Vadagaonkar and A. C. Chaskar, Asian J. Org. Chem., 2017, 6, 1579-1583.

46 C. Dai, S. Deng, Q. Zhu and X. Tang, RSC Adv., 2017, 7, 44132-44135.

47 M. Ramamohan, R. Sridhar, K. Raghavendrarao, N. Paradesi, K. B. Chandrasekhar and S. Jayaprakash, Synlett, 2015, 26, 1096-1100.

48 H. Liu, T. Duan, Z. Zhang, C. Xie and C. Ma, Org. Lett., 2015, 17, 2932-2935.

49 Z. He, M. Bae, J. Wu and T. F. Jamison, Angew. Chem., Int. Ed., 2014, 53, 14451-14455.

50 N. Azizi and E. Batebi, Catal. Sci. Technol., 2012, 2, 24452448.

51 D. Shahabi and H. Tavakol, J. Mol. Liq., 2016, 220, 324-328.

52 D. Shahabi and H. Tavakol, J. Iran. Chem. Soc., 2017, 14, 135142.

53 Z. S. Gano, F. S. Mjalli, T. Al-Wahaibi and Y. Al-Wahaibi, Int. J. Chem. Eng. Appl., 2015, 6, 367-371.

54 H. Mąka, T. Spychaj and J. Adamus, RSC Adv., 2015, 5, 82813-82821.
55 N. Delgado-Mellado, M. Larriba, P. Navarro, V. Rigual, M. Ayuso, J. García and F. Rodríguez, J. Mol. Liq., 2018, 260, 37-43.

56 C. A. Ibarguen, A. Mosquera, R. Parra, M. S. Castro and J. E. Rodríguez-Páez, Mater. Chem. Phys., 2007, 101, 433-440.

57 C. F. Araujo, J. A. P. Coutinho, M. M. Nolasco, S. F. Parker, P. J. A. Ribeiro-Claro, S. Rudić, B. I. G. Soares and P. D. Vaz, Phys. Chem. Chem. Phys., 2017, 19, 17998-18009.

58 C. Yuan, K. Chu, H. Li, L. Su, K. Yang, Y. Wang and X. Li, Chem. Phys. Lett., 2016, 661, 240-245.

59 M. Hiroshi, K. Hideko and K. Ryôiti, Chem. Lett., 1973, 2, 1061-1066.

60 P. Pacák, Chem. Pap., 1991, 45, 227-232.

61 A. P. Abbott, G. Capper, D. L. Davies and R. Rasheed, Inorg. Chem., 2004, 43, 3447-3452.

62 A. Cojocaru, S. Costovici, L. Anicai and T. Visan, Metal. Int., 2008, 14, 38-46.

63 F. D. Bellamy and K. Ou, Tetrahedron Lett., 1984, 25, 839-842. 64 A. B. Gamble, J. Garner, C. P. Gordon, S. M. J. O'Conner and P. A. Keller, Synth. Commun., 2007, 37, 2777-2786.

65 X. Du, M. Zheng, S. Chen and Z. Xu, Synlett, 2006, 2006, 1953-1955.

66 Y. Watanabe, Y. Tsuji, T. Kondo and R. Takeuchi, J. Org. Chem., 1984, 49, 4451-4455.

67 M. L. Kantam, R. S. Reddy, K. Srinivas, R. Chakravarti, B. Sreedhar, F. Figueras and C. Venkat Reddy, J. Mol. Catal. A: Chem., 2012, 355, 96-101.

68 Z. Shokri, B. Zeynizadeh and S. A. Hosseini, J. Colloid Interface Sci., 2017, 485, 99-105.

69 B. Zeynizadeh, Z. Shokri and M. Hasanpour Galehban, Appl. Organomet. Chem., 2019, 33, e4771.

70 G. D. Ho, D. Tulshian, A. Bercovici, Z. Tan, J. Hanisak, S. Brumfield, J. Matasi, C. R. Heap, W. G. Earley, B. Courneya, R. Jason Herr, X. Zhou, T. Bridal, D. Rindgen, S. Sorota and S.-W. Yang, Bioorg. Med. Chem. Lett., 2014, 24, 4110-4113.

71 S. Yamabe and S. Yamazaki, J. Phys. Org. Chem., 2016, 29, 361-367. 